УДК 339.138 .1

DOI: https://doi.org/10.37320/2415-3583/11.28

Ярмолюк О.Я.

кандидат економічних наук, доцент, доцент кафедри маркетингу, Національний авіаційний університет

Фісун Ю.В.

старший викладач кафедри маркетингу, Національний авіаџійний університет

Шаповалова А.А. студентка,

Національний авіаџійний університет

\title{
СОЦАЛЬНІ МЕРЕЖІ ЯК СУЧАСНИЙ ІНСТРУМЕНТ ПРОСУВАННЯ
}

Соиіальні мережі вже досить давно належать до числа найбільи популярних платформ в Інтернеті. Подібні майданчики збирають величезну кількість людей і для багатьох є альтернативою радіо, телебаченню, друкованим виданням. Іх щзоня відвідують мільйони користувачів, які шукають спілкування, розваг та інформації. Це величезна аудиторія, яка, до того ж, зазвичай є зачікавленою у нових товарах та послугах. Не використовувати маркетологам иңю аудиторію для розвитку бізнесу просто неможливо. Тому сьогодні величезною популярністю користується просування в соиіальних мережах. Соціальні медіа надають широкі можливості для просування брендів, слугують ефективним каналом иільового трафіку. Але щзоб використовувати величезний потенціал SMM повною мірою, потрібно розробити чітку стратегію присутності компанії на медіамайданчиках.

Ключові слова: інтернет-маркетинг, сочіальні мережі, комунікачїі, контент, иільова аудиторія.

Постановка проблеми. Розвиток інформаційних технологій приводить до того, що в останне десятиліття простежується чітка тенденція до якісної зміни способу сприйняття навколишнього світу і комунікації людей. Крім особистих сторінок у соціальних мережах, із кожним роком з'являється все більше публічних корпоративних сторінок. Для компаній соціальні платформи $\epsilon$ незамінним інструментом для вибудовування відносин 3 аудиторією. У цій статті розглядається можливість корпоративного маркетингу в соціальних мережах, переваги і недоліки подібного каналу комунікації компанії з клієнтами.

Аналіз останніх досліджень і публікацій. Нині найпоширенішим здобутком із цієї проблематики серед зарубіжних маркетологів є праці М. Стелзнера [3], в яких висвітлюються сучасні методи просування в мережі Інтернет. Значний внесок у дослідження соціальних мереж як ефективного інструменту маркетингу зробив зарубіжний маркетолог Д. Халилов [1]. Сутність та порядок створення бренду у своїх працях розглядали зарубіжні вчені В. Перція та Л. Мамлєєва [2].

Мета статті полягає у дослідженні соціальних мереж як сучасного інструменту Інтернет-маркетингу, виділенні основних цілей SMM, аналізіпереваг та недоліків цього методу просування та оцінці ефективності використання різними бізнесами.

Виклад основного матеріалу. У сучасному світі інформаційних технологій одним із найбільш популярних методів просування стає використання мережі Інтернет. Маркетинговий потенціал використання веб-ресурсів надзви- чайно високий, а стрімкий розвиток мережі та iii можливостей 3 кожним роком змінюе і робить доступнішими методи, за допомогою яких компанії можуть контактувати зі своєю цільовою аудиторією. Інтернет-маркетинг дає змогу суттєво знизити витрати компанії на рекламу, розширити масштаби ведення бізнесу з мінімальними витратами, внаслідок чого вартість контакту зі споживачем скорочується в декілька разів.

Вартий уваги і той факт, що Інтернет зосереджує в собі безпрецедентний обсяг інформації про спосіб життя, інтереси, цінності людей. Завдання маркетолога - ретельно проаналізувати переваги покупців та створити ідеальні умови для прийняття ними рішення про покупку. Інтернет-маркетинг спрямований на доведення до покупців тієї надлишкової інформації, якої вони потребують для здійснення вибору.

Сьогодні уваги заслуговують безліч соціальних явищ, які дали поштовх розвитку нових рекламних інструментів і в підсумку сформували сучасний маркетинг. Одним із сучасних рекламних інструментів в Інтернеті $є$ соціальні мережі - медіаплатформи для спілкування користувачів, унікальний інструмент для побудови комунікації між людьми, групами, спільнотами. Середньостатистичний користувач соціальної мережі активний, відкритий до отримання нової інформації, що несе в собі величезний потенціал для маркетингової діяльності компаній в Інтернеті.

Social media marketing - це просування товарів, послуг, бренду в соціальних мережах, спосіб взаємодії компаній із цільовою аудиторією на соці- 
альних платформах, блогах, форумах, спільнотах. Результати соціологічних досліджень свідчать, що користувач Інтернету проводить у соціальних мережах у середньому 2 години на день, що робить SMM одним із найперспективніших інструментів Інтернет-маркетингу [1, с. 126].

Сьогодні найбільш популярними соціальними мережами в Україні є Facebook, Instagram, Tiktok та ін. Не менш ніж 70\% власників приватного бізнесу використовують соціальні медіа як канали для просування і вирішення інших бізнес-завдань.

Основні цілі просування у соціальних мережах:

1) залучення нових клієнтів;

2) підвищення лояльності покупців;

3) брендинг.

SMM - це не завжди тільки творчий процес, найчастіше це звичайний набір необхідних дій, який допомагає компаніям досягати своїх цілей. Але для того, щоби просування в мережі приносило вигоду, компаніям потрібно чітко розуміти, що вони хочуть отримати. Їм потрібно відповісти всього на кілька запитань: хто наші клієнти, на якому майданчику ми будемо вести кампанію, що будемо робити та що хочемо отримати на виході? Виразні і чіткі відповіді на ці питання вже є успіхом і допоможуть у подальшому сформувати правильну маркетингову стратегію.

Маркетингова стратегія - це елемент загальної стратегії компанії (корпоративної стратегіï), який описує, як компанія повинна використовувати свої обмежені ресурси для досягнення максимального результату у збільшенні продажів і їх прибутковості в довгостроковій перспективі [2, с. 187].

Перший крок, який необхідно зробити, - це визначитися 3 цільовою аудиторією для подальшого правильного позиціонування. Для успіху потрібно розуміти такі речі: де живуть клієнти (територія), їхні переваги, стать, платоспроможність. Надалі ці дані будуть корисними для використання в таргетинговій рекламі.

Важливим моментом у розробленні маркетингової стратегії стає питання про ціль присутності в Інтернет-просторі. Цілі компанії в реальності і в мережі повинні якщо не збігатися, то як мінімум не суперечити одна одній. Якщо в реальному світі ставиться завдання підвищення продажів, то робота в соціальних мережах буде спрямована на залучення клієнтів і підвищення їхньої інформованості. $\mathrm{Hi}$ в якому разі компанія не повинна виходити в мережу тільки тому, що всі так роблять. Не всі майданчики підходять для вирішення поставлених завдань, кожен сервіс має власний унікальний набір функціональних характеристик, тому завдання маркетолога полягає в тому, щоб вивчити і підібрати максимально відповідний цілям кампанії.

Наступним кроком є розроблення контент-стратегії. Контент - будь-яке інформаційно значуще наповнення інформаційного ресурсу (наприклад, web-сайту) - тексти, графіка, мультимедіа - вся інформація, яку користувач може завантажити на диск комп'ютера 3 дотриманням відповідних законів, як правило, тільки для особистого користування. Якісний контент стане головною причиною залучення людей на сторінку компанії, він підвищує зацікавленість, допомагає в побудові саме довгострокових відносин зі споживачем. Тематика записів завжди підлаштовується під запити середньостатистичного цільового споживача, а найкращим способом планування маркетингової діяльності в Інтернеті стане календарний план публікацій і заходів. Тут важливо створити чіткий, гармонійний і цікавий образ компанії, який буде регулярно підтримуватися відповідним контентом.

Як і інші бізнес-процеси, Інтернет-маркетинг потребує контролю, актуалізації та оптимізації. За допомогою підібраних метрик можна зрозуміти, що подобається клієнтам, а що залишається без уваги, прорахувати вартість контакту зі споживачем. Їх вибір безпосередньо залежить від поставлених цілей. Вони можуть бути абсолютно різними: загальний трафік, кількість переходів на основний сайт, кількість аудиторії тощо.

Сьогодні головна перевага соціальних мереж полягає у тому, що вони сконцентрували велику масу людей в одному місці, незалежно від їхнього справжнього місця знаходження. Фахівці не часто виокремлюють цю перевагу для просування у соціальних мережах, але саме вона $є$ ключовою.

Ще однією перевагою $є$ те, що сегментування в мережі можливо робити набагато точніше, ніж у реальності. Сегментація ринку - процес розподілення споживачів на ринку на різні групи (або сегменти), в межах яких споживачі мають схожі або аналогічні запити, що задовольняються певним комплексом маркетингу. Соціальні мережі 3 легкістю допоможуть у цьому, досить просто налаштувати в пошуковому запиті конкретний діапазон вікових груп і територіальну приналежність і за допомогою виданих результатів підібрати цільову аудиторію. Це дає змогу працювати точно та високоефективно, також немає необхідності витрачатися на маркетингові дослідження 3 вивчення аудиторії, оскільки користувачі під час реєстрації вже вказали свої дані, які в майбутньому допоможуть маркетологам максимально чітко сформулювати рекламну кампанію.

Наступний аргумент на користь соціальних мереж - це посилений зворотний зв'язок. У мережі покупці набагато точніше і правдивіше висловлюють свою думку про продукт, і у керівника $є$ можливість оперативно реагувати на відгуки, що дає можливість здійснювати ретельний контроль за роботою персоналу.

Водночас в Інтернеті з'явилася та ж тенденція, що й у реальному світі: велика кількість реклами просто блокується мозком як непотрібна інформа- 
ція. Кількість реклами, яку щодня споживає середньостатистична людина, просто величезна. Починаючи від реклами на радіо і білбордів по дорозі на роботу і закінчуючи телевізійною рекламою між вечірніми шоу по телевізору - ве це сприяє розвитку у людей несприйнятливості до реклами. Саме тому легше запам'ятати рекламу, але зовсім забути про товар, який у ній рекламується. Вперше це довели в американському рекламному агентстві «Benway i Lane» і назвали це «банерною сліпотою». Соціальні мережі дають змогу обійти цей бар'єр, адже людина більш лояльно оцінює ту інформацію, якою діляться друзі, тому що людям часто важлива думка інших. До того ж, під час вступу до спільноти або підписки на публічну сторінку користувач уже подумки погоджується сприймати всю ту інформацію, яка буде до нього йти 3 цього джерела.

Далі слід перерахувати проблеми, які виникають під час використання SMM-маркетингу. Для кожного інтернет-ресурсу властивий свій контингент користувачів. Наприклад, Facebook використовують для спілкування люди, які більш просунуті у професійному плані, ті, що стежать за актуальними новинами, обговорюють статті та публікації. Соціальна мережа «Instagram» $\epsilon$ агрегатором людей різного віку та інтересів. С думка про те, що основна маса користувачів цієї мережі - школярі та студенти, проте це не зовсім так, за кілька років існування колишні школярі вже подорослішали, і можна сміливо говорити, що середній вік користувачів - 20-30 років. Тут користувачі звикли переглядати яскравий та молодіжний контент, публікувати фото та вести прямі трансляції зі своїми підписниками. Залежно від контингенту користувачів конкретної мережі компаніям необхідно створювати різні маркетингові стратегії, в цьому і полягає складність.

Споживачі під час вибору соціальних мереж орієнтуються на більш зручний для себе функціонал, візуальне оформлення, але головна характеристика - кількість друзів, знайомих і однодумців у кожній конкретній мережі. Коли ми говоримо про успішне просування товарів або послуг у соціальних мережах, слід чітко розуміти, чи відповідає продукт цій мережі, чи ні. Для цього компанія повинна визначити свою цільову аудиторію, провести аналітику, на яких соціальних платформах зосереджена більша кількість необхідної аудиторії, де вони найбільш активні і сприйнятливі до нової інформації. Деякі компанії, приймаючи рішення про вихід у мережу, займають позицію відразу у всіх відомих онлайн-сервісах, проте чи виправдана така стратегія? Слід враховувати, що ведення публічних сторінок і спільнот вимагає регулярної присутності в мережі, оперативного зворотного зв'язку, постійного творчого процесу створення унікального, цікавого контенту. У разі розсіювання концентрації відразу на декількох проектах можна очікувати зниження ефективності маркетингової діяльності.

Також під час розроблення стратегії створення представництва компанії в мережах не варто недооцінювати високу конкуренцію, яку навіть можна охарактеризувати як досконалу. Бар'єри для входу на медіамайданчик відсутні, а інформованість покупців - майже 100\%. У таких умовах важливо налагоджувати контакт зі споживачами, вибудовувати довгострокові відносини, залучати клієнтів, думці яких будуть довіряти інші. Певною мірою Інтернет зрівнює шанси різних компаній, будь це маленьке виробництво або мережа, у разі грамотної маркетингової стратегії просування товару малий бізнес може отримувати навіть кращий комерційний ефект, ніж масштабне виробництво. «Для успішного ведення бізнесу потрібен гарний контент, увага до інших людей і відмова від нав'язливої реклами» [3, с. 154].

Великий бізнес отримує велику користь 3 використання медіа-сервісів як інструментів маркетингової діяльності. Корпорації вирішують такі завдання, як позиціонування, підвищення інформованості цільової аудиторії, збільшення лояльності та ін. У мережах присутні всі можливості для брендингу компанії або якогось окремого товару або послуги. Брендинг - це процес формування іміджу протягом тривалого періоду за допомогою висвітлення додаткової цінності, емоційного або раціонального представлення торгової марки або продукту, який робить його більш привабливим для кінцевого споживача [2, с. 201]. Великі компанії не ставлять головною метою присутності в Інтернеті підвищення продажів, їхні діï спрямовані на взаємодію з клієнтами. SMMменеджери великих компаній прагнуть перевести якомога більше користувачів у ранг «амбассадор бренду», ненав'язливо доводять до них місію компанії, іiі цінності та ідеали. Зацікавлені користувачі добровільно поширюють інформацію своєму оточенню, що істотно підвищує рівень довіри до бренду. Також особливістю SMM у бізнесі виступають такі функції, як робота 3 негативом і його нейтралізація. Важливо розуміти, коли негатив виникає природним чином, а коли ним керують з3овні. Грамотне управління негативом допоможе не тільки залучити нових клієнтів, але і повернути довіру тих, хто їі втратив.

Середній та малий бізнес через SMM вирішує інші завдання. Часто від мереж вони хочуть короткострокових ефектів, таких як оповіщення про акції, підвищення продажів, зворотний зв'язок із клієнтами. В основному це представники туризму, торгівлі та сфери послуг.

В2B (business to business) складніше від інших, але теж досить ефективно можна просувати через мережі. Прикладами можуть бути рекламні агент- 
ства, рекрутингові послуги, інформаційні технологіi. Часто в такому разі створюються спільноти за інтересами, в які з часом привертають відповідну аудиторію - людей, які цікавляться тематикою групи і найчастіше професійно пов'язані 3 нею.

Висновки. Сьогодні багато сфер бізнесу представлені в соціальних медіа, тому що SMM став невід'ємною частиною сучасного Інтернет-маркетингу. Цей інструмент дає змогу залучати користувача безпосередньо на корпоративні сторінки, a не через пошукові системи. SMM охоплює не тільки соціальні мережі, а й такі майданчики, як блоги, форуми, мережеві спільноти, різні медіаресурси, які передбачають активну комунікацію 3 користувачами. Таким чином, незважаючи на новизну методу, використання соціальних мереж стає все більш ефективним інструментом сучасного маркетингу. Найбільшою перевагою SMM є швидкий старт, простота у зверненні, точність і можливість постійної взаємодії 3 користувачами. Професійна робота із соціальними мережами і SMM-просування чинять позитивний вплив на впізнаванність бренду, лояльність, продажі та залучення аудиторії.

\section{Список використаних джерел:}

1. Халилов Д. Маркетинг в социальных сетях. Москва, 2014. 351 с.

2. Перция В., Мамлєєва Л. Анатомия бренда. Санкт-Петербург, 2007. 288c.

3. Стелзнер М. Контент-маркетинг. Новые методы привлечения клиентов в эпоху Интернета / пер. с англ. Д. Баймухаметовой и О. Терентьевой. Москва, 2013. 288 с.

\section{References:}

1. Xalylov D. (2014) Marketyng v sotsyalnux setyax [Marketing in social networks] Moscow: Mann. (in Russian)

2. Percija V., Mamleeva L. (2007) Anatomija brenda [The anatomy of brand]. Saint Petersburg: Vershina. (in Russian)

3. Stelzner M. (2013) Kontent-marketyng. Novye metody pryvlechenyya klyentov v epoxu Interneta [Content-marketing. New methods of attracting customers in the Internet era]. Moscow: Mann. (in Russian)

\section{Yarmoliuk Oleksii, Fisun Iuliia, Shapovalova Anastasiia} National Aviation University

\section{SOCIAL NETWORKS AS A MODERN TOOL OF PROMOTION}

The article is devoted to the study of social networks as a modern marketing tool of promotion. The terminology is researched - social networks, social media marketing, marketing strategy, content, market segmentation, branding. The marketing potential of using web resources is evaluated. It is revealed that internet marketing is aimed at bringing to the buyers an excess information they need to make the choice. The sociological research confirms the prospect of social media marketing as a tool of internet marketing. The most popular social networks in Ukraine are highlighted. It has been found that the main goals of social networking promotion are customer engagement, loyalty enhancement and branding. It is proved that for the promotion in the Internet the company must have own marketing strategy. The basic steps to start promoting a company on social networks are highlighted. Companies need to define their target audience for correct position themselves in the network. It is revealed that in order for a company to enter the Internet space, it must have a clear goal, which may be different from the company's goal in reality, but not to contradict it. The necessity of developing a content strategy for quality promotion of the company on the network is proved. It has been found that internet marketing needs constant monitoring to identify the strengths and weaknesses of content, optimize it, and find new ways to reach audiences. The main advantages and disadvantages of social media marketing are highlighted. The main characteristics of the audience of modern social networks are outlined. It is proved that the criteria for choosing social networks are visual design, functionality and the number of registered friends or like-minded people. It is determined that there are no barriers to entry for companies to the media market and the competition is perfect. It is justified that the size of the company is not essential for an effective promotion in the network, the commercial effect depends on a competent marketing strategy. Highlights the tasks that corporations solve with the help of Internet promotion. The specifics of the use of social media marketing in large, medium, small businesses and B2B are examined.

Key words: internet marketing, social networks, communications, content, target audience.

JEL classification: M30, M31, M37, M39. 